\title{
Determinants of Technological Diffusion via FDI Enterprises in the Manufacturing Sector in Vietnam over 2005-2013
}

\author{
Thanh Ngo-Quang1, Thong Le-Van², Phuc Doan-Ngoc ${ }^{3}$ \\ ${ }^{1}$ Institute of Policy and Strategy for Agricultural and Rural Development, Ha Noi, Vietnam \\ ${ }^{2}$ Academy of Politics Region II, Ho Chi Minh National Academy of Politics, Ho Chi Minh City, Vietnam \\ ${ }^{3}$ University of Finance-Marketing, Ho Chi Minh City, Vietnam \\ Email: thanh.ngo@scap.gov.vn, lethong0804@gmail.com, dnp hvct@yahoo.com.vn
}

Received 6 October 2015; accepted 21 October 2015; published 28 October 2015

Copyright (C) 2015 by authors and OALib.

This work is licensed under the Creative Commons Attribution International License (CC BY). http://creativecommons.org/licenses/by/4.0/

(c) (i) Open Access

\section{Abstract}

Much empirical research confirms that foreign enterprises are more efficient than domestic ones in the context of developing countries. However, while most studies support the hypothesis that foreign ownership participation increases performance of firms in terms of productivity and efficiency, some works find no differences, leading to a controversy on this issue. This study was designed to investigate and examine technological diffusion via FDI enterprises in manufacturing sector in Vietnam over the period 2005-2013. The paper finds that in general, the investigation revealed that FDI firms have more technical efficiency than domestic firms in most of manufacturing sub-sectors in Vietnam over the period 2005-2013. Factors affecting technological diffusion between all kinds of FDI and domestic manufacturing enterprises in Vietnam within the framework of this investigation are named as follows: 1) Firm's past performance: Positive relationship between firms' past performance and technical efficiency score, 2) Size of a firm in terms of labour and capital: Negative relationship between size of a firm in terms of labour and capital and technical efficiency scores, 3) The firms' financial performance: Positive relationship between firms' financial performance and technical efficiency scores, 4) The firms' level of self-financing: Negative relationship between firms' level of self-financing and technical efficiency scores, 5) The labour market conditions: Positive relationship between the labour market conditions and technical efficiency scores, 6) Years of operation: A quadratic relationship between Years of operation and technical efficiency scores, 7) FDI creates reverse effects in terms of firms' financial performance in terms of ROA, ROE on FDI firms' technical efficiency, 8) FDI creates reverse effects in terms of firms' characteristics (equity to assets ratio, capital, and labour) on FDI firms' technical efficiency. Wholly foreign-owned firms also create reverse effects in terms of equity to assets ratio on firms' technical efficiency. Moreover, wholly foreign-owned firms also create reverse effects in terms of labour on firms' technical efficiency. Paper also suggests some recommendations to policy makers and administrators at various levels in Vietnam. 


\title{
Keywords
}

\section{Technological Diffusion, Technical Efficiency, FDI, Manufacturing Sector, Vietnam}

\author{
Subject Areas: Business Analysis, Development Economics, Economics
}

\section{Introduction}

Continual interest in the comparative performance of domestic owned and foreign owned enterprises since policy makers have long believed that FDI can be an important source of technology for developing economies (World Bank [1]). They argue that foreign investment may generate some benefits for the host country. For example, by financing the expansion of business or the creation of new firms, it increases employment. It also may lead to the transfer of knowledge or new technologies from foreign to domestic firms and it may provide critical know-how to enable domestic plants to enter export markets (Harrison [2]). Much empirical research follows this line of interesting field of study and most of them confirm that foreign enterprises are more efficient than domestic ones in the context of developing countries (for example: Liu [3], Aydin, Sayim, and Yalam [4]). However, while most studies support the hypothesis that foreign ownership participation increases performance of firms in terms of productivity and efficiency, some works find no differences, leading to a controversy on this issue (for example: Rowland [5], Basti and Akin [6]).

Data available from Enterprise Censuses (EC) conducted by GSO of Vietnam give some thoughts on the comparative performance between domestic and foreign enterprises in Vietnam. Ngo-Quang [7] found that: 1) among enterprises of many kinds, domestic state-owned enterprises prove to be more efficient in terms of profit to capital ratio, profit to equity ratio, and labour productivity than foreign ones, 2) by splitting foreign enterprises into three types, namely wholly foreign-owned, state-owned with foreign and domestic private with foreign enterprises, state-owned enterprise turns to be the most efficient ones in terms of labour productivity. However, state-owned enterprises still prove to be dominant in terms of both profit to capital and profit to equity ratios, 3) among foreign capital enterprises, wholly foreign-owned enterprise is seemingly less efficient in terms of labour productivity, profit to capital and profit to equity ratios than domestic private with foreign partner, 4) sometimes, enterprises are more efficient in terms of profit to capital ratio but less in terms of profit to equity ratio. Therefore, controversies raise the following main research question: What are the factors affecting technological diffusion between all kinds of FDI and domestic manufacturing enterprises in Vietnam?

We view that the influx of more advanced technology introduced by foreign firms alters the practice of domestically owned firms and leads to improvements in their technical efficiency levels. In the present study, the researcher attempts to measure FDI enterprises' impact on domestic firms' technical efficiency and identify the presence of either positive technological spillovers caused by FDI enterprises' to domestic firms, or reverse technological spillovers as these are defined by (Driffield \& Love [8]). In so doing, the researcher uses the method of estimating technical efficiency from a stochastic frontier production function as proposed by Battese \& Coelli [9] to estimate the technical efficiency scores for each firm (foreign and domestic) operating in a sector and reports the evolution of the technical efficiency gap between the two groups of firms. Nevertheless, to attribute the observed technical efficiency gap solely to FDI presence will be misleading, since other firm specific variables may contribute to a firm's observed efficiency level and the corresponding technical efficiency gap. Thus, the researcher attempts to identify the true potential effect of FDI enterprises' presence by controlling for other driving forces that affect the efficiency levels of the operating firms. Technological diffusion is then defined as the evolution of the efficiency gap, between the FDI enterprises and the domestic firms that operate in a country, which can be attributed purely to FDI with the diffusion taking place when this efficiency gap is reduced over time.

The following section of this paper presents an overall evidence of technological diffusion in the manufacturing sector. Section 3 is about regression analysis of determinants of technological diffusion via FDI in the manufacturing sector. Conclusion and recommendations end this paper.

\section{Overall Evidence of Technological Diffusion in the Manufacturing Sector}

Summary statistics of the technical efficiency scores by year and ownership type are presented in Table 1. 
From Table 1, we observe that before 2010 FDIs' technical efficiency levels were less than that of domestic firms' by 1 - 3 per cent every year, with 2009 reaching at maximum at 3 per cent. From 2010, FDIs' technical efficiency levels exceeded that of domestic firms' by 1 - 3 per cent every year, with 2011 reaching 3 per cent. Table 1 also shows that the technical efficiency performance gap (MeanTEFDI-MeanTEDOM) remains statistically significant at 5 or 1 per cent significance level during the period 2007-2013 in our sample. The gap is around 1 - 2 per cent in recent years. In addition, before 2010, FDIs' technical efficiency levels display higher standard deviations, indicating that FDI firms are less homogeneous than domestic firms. However, from 2010, FDIs' technical efficiency levels display lower standard deviations, indicating that FDI firms are more homogeneous than domestic firms.

Closer look at FDI types gives summary statistics of the technical efficiency scores by year and ownership type between domestic firms and FDI ones in Table 2. In Table 2, we observe that before 2010 wholly foreignowned firms' technical efficiency levels were less than that of domestic firms' by 1 - 4 per cent every year, with 2009 reaching at maximum at 4 per cent. From 2010, wholly foreign-owned firms' technical efficiency levels were exceed that of domestic firms' by 1 - 3 per cent every year, with 2011 reaching 3 per cent. Table 2 also shows that the technical efficiency performance gap (MeanTEFDI-MeanTEDOM) remains statistically significant at 1 per cent significance level in our sample, except for year 2012. The gap is around 1 per cent in recent years. In addition, before 2010, wholly foreign-owned firms' technical efficiency levels display higher standard deviations, indicating that FDI firms are less homogeneous than domestic firms. However, from 2010, wholly foreign-owned firms' technical efficiency levels display lower standard deviations, indicating that FDI firms are more homogeneous than domestic firms.

Table 1. Statistics on technical efficiency between domestic vs. FDI firms, 2005-2013.

\begin{tabular}{ccccccccccc}
\hline Firm & $\mathbf{2 0 0 5}$ & $\mathbf{2 0 0 6}$ & $\mathbf{2 0 0 7}$ & $\mathbf{2 0 0 8}$ & $\mathbf{2 0 0 9}$ & $\mathbf{2 0 1 0}$ & $\mathbf{2 0 1 1}$ & $\mathbf{2 0 1 2}$ & $\mathbf{2 0 1 3}$ \\
\hline Dom. & 0.41 & 0.40 & 0.43 & 0.41 & 0.44 & 0.33 & 0.29 & 0.33 & 0.33 \\
FDI & 0.41 & 0.39 & 0.43 & 0.39 & 0.41 & 0.35 & 0.32 & 0.33 & 0.34 \\
Diff. of means & 0.00 & -0.01 & -0.01 & -0.02 & -0.03 & 0.02 & 0.03 & 0.01 & 0.02 \\
Z-Stat. & 0.15 & & & $5.30^{* * *}$ & & $6.59^{* * *}$ & $11.58^{* * *}$ & $1.87^{* *}$ & $5.98^{* * *}$ \\
N & 20,468 & 23,968 & 20,162 & 29,613 & 36,614 & 42,417 & 45,217 & 52,423 & 56,247 \\
\hline
\end{tabular}

Sources: Authors' calculation from EC 2005-2013. Note: ${ }^{*} p<0.1 ;{ }^{* *} p<0.05 ;{ }^{* * *} p<0.01$.

Table 2. Statistics on technical efficiency scores between domestic vs. various types of FDI firms, 2005-2013.

\begin{tabular}{|c|c|c|c|c|c|c|c|c|c|}
\hline Firm & 2005 & 2006 & 2007 & 2008 & 2009 & 2010 & 2011 & 2012 & 2013 \\
\hline Dom. & 0.41 & 0.40 & 0.43 & 0.41 & 0.44 & 0.33 & 0.29 & 0.33 & 0.33 \\
\hline Wholly foreign-owned & 0.40 & 0.38 & 0.42 & 0.38 & 0.40 & 0.34 & 0.32 & 0.33 & 0.34 \\
\hline SOE with FDI & 0.49 & 0.49 & 0.55 & 0.52 & 0.54 & 0.43 & 0.42 & 0.45 & 0.42 \\
\hline PTE with FDI & 0.42 & 0.40 & 0.43 & 0.43 & 0.45 & 0.37 & 0.34 & 0.33 & 0.35 \\
\hline \multicolumn{10}{|c|}{ Domestic vs. wholly foreign-owned } \\
\hline Mean deff. & -0.01 & -0.02 & -0.02 & -0.03 & -0.04 & 0.01 & 0.03 & 0.00 & 0.01 \\
\hline Z-Statistic & & & & & & $4.35^{* * *}$ & $9.10^{* * *}$ & 0.32 & $4.54^{* * *}$ \\
\hline $\mathrm{N}$ & 20,034 & 23,533 & 19,732 & 29,177 & 36,175 & 41,963 & 44,747 & 51,924 & 55,773 \\
\hline \multicolumn{10}{|c|}{ Domestic vs. SOE with FDI } \\
\hline Mean deff. & 0.08 & 0.09 & 0.11 & 0.11 & 0.10 & 0.11 & 0.13 & 0.12 & 0.09 \\
\hline Z-Stat. & $7.42^{* * *}$ & $7.94^{* * *}$ & $10.09^{* * *}$ & $8.78^{* * *}$ & $7.32^{* * *}$ & $7.85^{* * *}$ & $9.46^{* * *}$ & $8.32^{* * *}$ & $6.39^{* * *}$ \\
\hline $\mathrm{N}$ & 18,405 & 21,561 & 17,534 & 26,503 & 33,075 & 38,491 & 41,083 & 47,707 & 51,466 \\
\hline \multicolumn{10}{|c|}{ Domestic vs. PTE with FDI } \\
\hline Mean deff. & 0.01 & 0.00 & -0.01 & 0.02 & 0.00 & 0.04 & 0.05 & 0.01 & 0.03 \\
\hline Z-Stat. & 0.74 & 0.01 & & $1.82^{*}$ & 0.12 & $3.80^{* * *}$ & $4.84^{* * *}$ & 0.50 & $2.62^{* * *}$ \\
\hline $\mathrm{N}$ & 18,327 & 21,526 & 17,532 & 26,531 & 33,138 & 38,581 & 41,213 & 47,886 & 51,658 \\
\hline
\end{tabular}

Sources: Authors' calculation from EC 2005-2013. Note: ${ }^{*} p<0.1 ;{ }^{* *} p<0.05 ; \stackrel{* * *}{p}<0.01$. 
In Table 2, we also observe that FDI with SOE firms' technical efficiency levels were always higher than that of domestic firms' by 8 - 13 per cent every year in our sample, with 2011 reaching at maximum at 11 per cent. Table 2 also shows that the technical efficiency performance gap (MeanTEFDI-MeanTEDOM) remains statistically significant at 1 per cent significance level in our sample. In addition, FDI with SOE firms' technical efficiency levels display higher standard deviations, indicating that FDI with SOE firms are less homogeneous than domestic firms.

In Table 2, we also find that FDI with PTE firms' technical efficiency levels were higher than that of domestic firms' by 1 - 5 per cent in our sample (except for 2007), with 2011 reaching at maximum at 5 per cent. Table 2 also shows that the technical efficiency performance gap (MeanTEFDI-MeanTEDOM) remains statistically significant at 1 per cent significance level in recent years. In addition, FDI with PTE firms' technical efficiency levels display higher standard deviations, indicating that FDI with PTE firms are less homogeneous than domestic firms.

\section{Regression Analysis of Determinant of Technological Diffusion}

\subsection{Data Description}

Description of the variables used in the estimations is presented in Table 3.

\subsection{Model Specification}

The existence and the evolution of the efficiency gap between the domestically and foreign owned firms in Section 2 might not always be due to the ownership type but to other relevant factors; if such factors exist then it would be misleading to interpret the efficiency gap solely due to the presence of FDI. Thus, it becomes imperative to take into account the impact of these relevant factors on the level of the production outcome and to distinguish between the part of the estimated efficiency attributed to the ownership type or to other factors. Additionally, it is required to study this impact on an annual basis in order to examine its effect diachronically on the efficiency scores and on the respective evolution of the efficiency gap. Thus, in the second stage of the analysis the basic model specification employed is:

$$
\text { TECH_DIFF }{ }_{\text {it }}=\delta_{0}+\delta_{1} \text { FIRMC }_{\text {it }}+\delta_{2} \text { FIRMP }_{\text {it }}+\delta_{3} \text { MARKET }_{\text {it }}+\mathrm{w}_{\mathrm{it}}
$$

where: TECH_DIFF is technological diffusion, FIRMC is a vector of firm characteristics (including firm size, firm's age, level of self-financing), FIRMP is a vector of firm performance (including indicators of profitability

Table 3. Description of the variables used in the technological diffusion model, 2005-2013.

\begin{tabular}{|c|c|}
\hline Variable & Description \\
\hline tech_ & Technical efficiency at time $\mathrm{t}$ \\
\hline L. tech_ & Technical efficiency at time t-1 \\
\hline log_laodong_ & Natural logarithm of labor \\
\hline log_von_ & Natural logarithm of fixed capital (assets) \\
\hline age & Years of operations \\
\hline age 2 & Years squared of operations \\
\hline age 3 & Years quadatic of operations \\
\hline equity_to_assets & Equity to total assets \\
\hline roa_ & Return on assets \\
\hline roe_ & Return on equity \\
\hline own & $\begin{array}{l}\text { Dummies for types of ownership } \\
\text { Case 1: } 1 \text { if domestic firm, } 0 \text { if FDI firm (variable: grouptwo) } \\
\text { Case 2: } 0 \text { if domestic, } 1 \text { if FDI with } 100 \%, 2 \text { if SOE with FDI, and } 3 \text { if PTE with FDI (variables: group1_, group2_, } \\
\text { group3_, group4_,) }\end{array}$ \\
\hline wage_ & Wages per person in a firm \\
\hline
\end{tabular}

Source: Author's compilation. 
such as ROA or ROE), and MARKET is a vector of labour market conditions.

$\mathrm{W}_{\mathrm{t}}$ is error terms which are assumed to be independently and identically distributed followed by the truncation of the normal distribution with zero mean and unknown variance $\sigma_{\mathrm{w}}^{2}$.

The inclusion of variable OWN in the above specification serves as a proxy to FDI presence and allows us to quantify its impact on technical efficiency after taking into account the respective effect of other control variables. Hence, the ownership type implies a difference (or lack in the case of a not statistically significant coefficient) in the efficiency level. Furthermore, it holds information whether the observed efficiency gap can be attributed to the presence of FDI or to other factors.

In the second stage of the present analysis reports the results of four different model specifications. The first specification (Model 1) contains the basic model described in Equation (3), while the other three are its extensions with the inclusion of interaction terms between variable OWN and the other explanatory variables.

In model 1, the author presents Model 1a (firm size proxied by labour, and firm performance proxied by ROA), Model 1b (firm size proxied by labour, and firm performance proxied by ROE), Model 1c (firm size proxied by capital, and firm performance proxied by ROA), and Model 1d (firm size proxied by capital, and firm performance proxied by ROE).

In Model 2 the author introduces the interaction variable OWN*ROA or OWN*ROE to isolate the effect of foreign ownership on the financial performance of a firm in terms of its ROA (or ROE) index. Model 2 is defined as follows:

$$
\text { TECH_DIFF }{ }_{\text {it }}=\delta_{0}+\delta_{1} \text { FIRMC }_{\text {it }}+\delta_{2} \text { FIRMP }_{\text {it }}+\delta_{3} \mathrm{MARKET}_{\text {it }}+\delta_{4} \mathrm{OWN}_{\mathrm{i}} \mathrm{ROA}_{\text {it }}\left(\mathrm{ROE}_{\mathrm{it}}\right)+\mathrm{w}_{\mathrm{it}}
$$

In model 2, the author presents Model 2.1a (ownership categorized by two types namely domestic and FDI firms, firm size proxied by labor, and firm performance proxied by ROA), Model 2.1b (ownership categorized by two types namely domestic and FDI firms, firm size proxied by labour, and firm performance proxied by ROE), Model 2.1c (ownership categorized by two types namely domestic and FDI firms, firm size proxied by capital, and firm performance proxied by ROA), and Model 2.1d (ownership categorized by two types namely domestic and FDI firms, firm size proxied by capital, and firm performance proxied by ROE).

In model 2, the author also presents Model 2.2a (ownership categorized by four types namely: domestic, wholly foreign-owned, SOE with FDI and PTE with FDI firms, firm size proxied by labour, and firm performance proxied by ROA), Model 2.2b (ownership categorized by four types namely: domestic, wholly foreignowned, SOE with FDI and PTE with FDI firms, firm size proxied by labour, and firm performance proxied by ROE), Model 2.2c (ownership categorized by four types namely: domestic, wholly foreign-owned, SOE with FDI and PTE with FDI firms, firm size proxied by capital, and firm performance proxied by ROA), and Model 2.2d (ownership categorized by four types namely: domestic, wholly foreign-owned, SOE with FDI and PTE with FDI firms, firm size proxied by capital, and firm performance proxied by ROE).

Model 3 is the basic model with the inclusion of the interaction variable $\mathrm{OWN} * \mathrm{SF}$ which addresses the effect of foreign ownership on the degree of self-financing:

$$
\text { TECH_DIFF }{ }_{\text {it }}=\delta_{0}+\delta_{1} \text { FIRMC }_{\text {it }}+\delta_{2} \text { FIRMP }_{\text {it }}+\delta_{3} \text { MARKET }_{\text {it }}+\delta_{4} \mathrm{OWN}_{\mathrm{i}} \mathrm{SF}_{\mathrm{it}}+\mathrm{w}_{\mathrm{it}}
$$

In model 3, the author presents Model 3.1a (ownership categorized by two types namely domestic and FDI firms, firm size proxied by labour, and firm performance proxied by ROA), Model 3.1b (ownership categorized by two types namely domestic and FDI firms, firm size proxied by labour, and firm performance proxied by ROE), Model 3.1c (ownership categorized by two types namely domestic and FDI firms, firm size proxied by capital, and firm performance proxied by ROA), and Model 3.1d (ownership categorized by two types namely domestic and FDI firms, firm size proxied by capital, and firm performance proxied by ROE).

In model 3, the author also presents Model 3.2a (ownership categorized by four types namely: domestic, wholly foreign-owned, SOE with FDI and PTE with FDI firms, firm size proxied by labour, and firm performance proxied by ROA), Model 3.2b (ownership categorized by four types namely: domestic, wholly foreign-owned, SOE with FDI and PTE with FDI firms, firm size proxied by labour, and firm performance proxied by ROE), Model 3.2c (ownership categorized by four types namely: domestic, wholly foreign-owned, SOE with FDI and PTE with FDI firms, firm size proxied by capital, and firm performance proxied by ROA), and Model 3.2d (ownership categorized by four types namely: domestic, wholly foreign-owned, SOE with FDI and PTE with FDI firms, firm size proxied by capital, and firm performance proxied by ROE).

Finally, Model 4 incorporates the impact of foreign ownership on firm size (either proxied by labour or capi- 
tal) by adding the interaction variable $\mathrm{OWN} * \mathrm{SIZE}$ :

$$
\text { TECH_DIFF }{ }_{\text {it }}=\delta_{0}+\delta_{1} \text { FIRMC }_{\text {it }}+\delta_{2} \text { FIRMP }_{\text {it }}+\delta_{3} \text { MARKET }_{\text {it }}+\delta_{4} \mathrm{OWN}_{\mathrm{i}} \mathrm{SIZE}_{\mathrm{it}}+\mathrm{w}_{\mathrm{it}}
$$

In model 4, the author presents Model 4.1a (ownership categorized by two types namely domestic and FDI firms, firm size proxied by labour, and firm performance proxied by ROA), Model 4.1b (ownership categorized by two types namely domestic and FDI firms, firm size proxied by labour, and firm performance proxied by ROE), Model 4.1c (ownership categorized by two types namely domestic and FDI firms, firm size proxied by capital, and firm performance proxied by ROA), and Model 4.1d (ownership categorized by two types namely domestic and FDI firms, firm size proxied by capital, and firm performance proxied by ROE).

In model 4, the author also presents Model 4.2a (ownership categorized by four types namely: domestic, wholly foreign-owned, SOE with FDI and PTE with FDI firms, firm size proxied by labour, and firm performance proxied by ROA), Model 4.2b (ownership categorized by four types namely: domestic, wholly foreign-owned, SOE with FDI and PTE with FDI firms, firm size proxied by labour, and firm performance proxied by ROE), Model 4.2c (ownership categorized by four types namely: domestic, wholly foreign-owned, SOE with FDI and PTE with FDI firms, firm size proxied by capital, and firm performance proxied by ROA), and Model 4.2d (ownership categorized by four types namely: domestic, wholly foreign-owned, SOE with FDI and PTE with FDI firms, firm size proxied by capital, and firm performance proxied by ROE).

Before ending with the suitable form of model, since data are panel thus it needs to check which type of estimation methods is the best between Fixed Effects Model and Random Effects Model. The Hausman specification test show that the $\mathrm{H}_{0}$ that the $\mathrm{RE}$ estimator is consistent (due to non-zero covariance between residuals and explanatory variables) is rejected. Therefore, we have to rely upon the FE estimator.

\subsection{Basic Model of Technological Diffusion}

Table 4 presents the regression results of Model 1, which is regressed by method of Fixed Effects Model of panel data. Around 22 - 24 per cent of a firm's efficiency score may be attributed to its past performance indicating the strong impact of factors embedded in the firm's operating process.

The SIZE variable shows a statistically significant negative effect on the level of technical efficiency scores for all basic model specifications. Acs et al. [10] state that small firms create innovation by exploiting the knowledge that was created by their larger counterparts whereas the large firms tend to get bogged down in developing those innovations in their own firms. In addition, OECD [11] points out that since small and medium

Table 4. Technological diffusion model in the manufacturing sector in Vietnam (Model 1), 2005-2013.

\begin{tabular}{|c|c|c|c|c|}
\hline Variable & Model 1a & Model 1b & Model 1c & Model 1d \\
\hline L.tech_ & $0.226^{* * *}$ & $0.246^{* * *}$ & $0.216^{* * *}$ & $0.236^{* * *}$ \\
\hline log_ldong_ & $-0.034^{* * *}$ & $-0.032^{* * *}$ & & \\
\hline age & $-0.015^{* * *}$ & $-0.012^{* * *}$ & $-0.010^{* * *}$ & $-0.007^{* * *}$ \\
\hline age 2 & $-0.000^{* *}$ & $-0.000^{* * *}$ & $-0.000^{* * *}$ & $-0.001^{* * *}$ \\
\hline age 3 & $0.000^{*}$ & $0.000^{* * *}$ & $0.000^{* * *}$ & $0.000^{* * *}$ \\
\hline equity_to_assets_ & $-0.022^{* * *}$ & $-0.016^{* * *}$ & $-0.025^{* * *}$ & $-0.0236^{* * *}$ \\
\hline roa_ & $0.033^{* * *}$ & & $0.018^{* * *}$ & \\
\hline wage_ & $0.000^{* * *}$ & $0.000^{* * *}$ & $0.001^{* * *}$ & $0.001^{* * *}$ \\
\hline roe_ & & $0.000^{* * *}$ & & $0.000^{* * *}$ \\
\hline log_von_ & & & $-0.023^{* * *}$ & $-0.024^{* * *}$ \\
\hline Constant & $0.66^{* * *}$ & $0.62^{* * *}$ & $0.66^{* * *}$ & $0.64^{* * *}$ \\
\hline Observations & 10,852 & 9,762 & 10,852 & 9,762 \\
\hline R-squared & 0.219 & 0.205 & 0.254 & 0.245 \\
\hline Number of id & 1,392 & 1,392 & 1,392 & 1,392 \\
\hline F test that all $\mathrm{u} \_\mathrm{i}=0$ & $3.46^{* * *}$ & $3.02^{* * *}$ & $3.83^{* * *}$ & $3.41^{* * *}$ \\
\hline
\end{tabular}

Sources: Authors' calculation from EC 2005-2013. Note: Standard errors in parentheses; 0.000 : less than $0.001 ;{ }^{* * *} p<0.01,{ }^{* *} p<0.05,{ }^{*} p<0.1$. 
firms have a limited ability of internal R \& D, they depend more on external source technology than the large firms. In terms of labour, around 0.03 per cent of a firm's efficiency score decreased may be attributed to its increase of $1 \%$ in employees, ceteris paribus. Similarly, in terms of capital, around 0.02 per cent of a firm's efficiency score decreased may be attributed to its increase of $1 \%$ in fixed assets, ceteris paribus.

The two financial performance variables, ROA and ROE, display a significant impact on TE, as well. Variable ROA, in all basic model specifications, exerts a positive and statistically significant impact (of about $2 \%$ $3 \%$ ) on technical efficiency scores, ceteris paribus, confirming that firms with higher profitability demonstrate better levels of technical efficiency scores as they are able to grow faster and adjust quicker to new technologies and changing economic environment. Similarly, variable ROE, in all basic model specifications, exerts a positive and statistically significant impact (of about $0.02 \%$ ) on technical efficiency scores, ceteris paribus.

The level of self-financing (ETA) exerts a negative impact on technical efficiency scores ranging between -2.0 per cent and -3.0 per cent in all basic model specifications indicating that firms with increased levels of external financing display an aggressive and expanding behaviour which leads them to higher technical efficiency levels.

The data indicates that years of operation have a quadratic relationship with technical efficiency and are significant at 1 percent level, in all basic model specifications.

\subsection{Model of Technological Diffusion with the Impact of Ownership over Firm Performance}

In Model 2.1 we introduce the interaction variable GROUPTWO*ROA or GROUPTWO*ROE to isolate the effect of foreign ownership on the financial performance of a firm in terms of its ROA (or ROE) index. The estimation results are in Table 5 in which ownership variable has two categories: 1 if domestic, 0 if FDI. The results from all specifications of Model 2.1 appear to be consistent and robust with those of Model 1 with respect to variables such as lag of technical efficiency, labour, capital, ages at three forms, equity to assets, and wage in terms of signs, magnitude of coefficients.

Table 5. Technological diffusion model in the manufacturing sector in Vietnam (Model 2), 2005-2013.

\begin{tabular}{|c|c|c|c|c|c|c|c|c|}
\hline VARIABLES & Model 2.1a & Model 2.1b & Model 2.1c & Model 2.1d & Model 2.2a & Model 2.2b & Model 2.2c & Model 2.2d \\
\hline L. tech_ & $0.225^{* * *}$ & $0.245^{* * *}$ & $0.215^{* * *}$ & $0.235^{* * *}$ & $0.225^{* * *}$ & $0.245^{* * *}$ & $0.215^{* * *}$ & $0.235^{* * *}$ \\
\hline log_ldong_ & $-0.034^{* * *}$ & $-0.032^{* * *}$ & & & $-0.034^{* * *}$ & $-0.032^{* * *}$ & & \\
\hline age & $-0.015^{* * *}$ & $-0.012^{* * *}$ & $-0.010^{* * *}$ & $-0.007^{* * *}$ & $-0.015^{* * *}$ & $-0.012^{* * *}$ & $-0.010^{* * *}$ & $-0.007^{* * *}$ \\
\hline age2 & $-0.000^{* * *}$ & $-0.000^{* * *}$ & $-0.000^{* * *}$ & $-0.001^{* * *}$ & $-0.000^{* * *}$ & $-0.000^{* * *}$ & $-0.000^{* * *}$ & $-0.001^{* * *}$ \\
\hline age3 & $0.000^{* *}$ & $0.000^{* * *}$ & $0.000^{* * *}$ & $0.000^{* * *}$ & $0.000^{* *}$ & $0.000^{* * *}$ & $0.000^{* * *}$ & $0.000^{* * *}$ \\
\hline equity_to_assets_ & $-0.021^{* * *}$ & $-0.016^{* * *}$ & $-0.024^{* * *}$ & $-0.024^{* * *}$ & $-0.021^{* * *}$ & $-0.016^{* * *}$ & $-0.024^{* * *}$ & $-0.024^{* * *}$ \\
\hline roa_ & $0.061^{* * *}$ & & $0.035^{* * *}$ & & $0.0614^{* * *}$ & & $0.035^{* * *}$ & \\
\hline wage_ & $0.000^{* * *}$ & $0.000^{* * *}$ & $0.001^{* * *}$ & $0.001^{* * *}$ & $0.000^{* * *}$ & $0.000^{* * *}$ & $0.001^{* * *}$ & $0.001^{* * *}$ \\
\hline grouptwo_roa & $-0.035^{* * *}$ & & $-0.020^{*}$ & & & & & \\
\hline roe_ & & $0.000^{* * *}$ & & $0.000^{* * *}$ & & $0.000^{* * *}$ & & $0.000^{* * *}$ \\
\hline grouptwo_roe & & $-0.000^{* *}$ & & $-0.000^{* * *}$ & & & & \\
\hline log_von_ & & & $-0.023^{* * *}$ & $-0.024^{* * *}$ & & & $-0.023^{* * *}$ & $-0.024^{* * *}$ \\
\hline group 1_roa & & & & & $-0.035^{* * *}$ & & $-0.020^{*}$ & \\
\hline group 1_roe & & & & & & $-0.000^{* *}$ & & $-0.000^{* * *}$ \\
\hline Constant & $0.67^{* * *}$ & $0.62^{* * *}$ & $0.66^{* * *}$ & $0.64^{* * *}$ & $0.67^{* * *}$ & $0.62^{* * *}$ & $0.66^{* * *}$ & $0.64^{* * *}$ \\
\hline Observations & 10,852 & 9762 & 10,852 & 9762 & 10,852 & 9762 & 10,852 & 9762 \\
\hline R-squared & 0.22 & 0.21 & 0.25 & 0.25 & 0.22 & 0.21 & 0.25 & 0.25 \\
\hline Number of id & 1392 & 1392 & 1392 & 1392 & 1392 & 1392 & 1392 & 1392 \\
\hline F test that all $u_{-} i=0$ & $3.47^{* * *}$ & $3.03^{* * *}$ & $3.83^{* * *}$ & $3.41^{* * *}$ & $3.47^{* * *}$ & $3.03^{* * *}$ & $3.83^{* * *}$ & $3.41^{* * *}$ \\
\hline
\end{tabular}

Sources: Authors' calculation from EC 2005-2013. Note: Standard errors in parentheses; 0.000 : less than $0.001 ;{ }^{* * *} p<0.01, \stackrel{* *}{p}<0.05, \stackrel{*}{p}<0.1$. 
Variable ROA and ROE, in all specifications of Model 2.1, exerts a positive and statistically significant impact on technical efficiency scores, confirming that firms with higher profitability demonstrate better levels of technical efficiency scores as they are able to grow faster and adjust quicker to new technologies and changing economic environment. However, the magnitudes are higher than that in Model 1. For example, in Model 1, the coefficient of ROA is 0.0331, whereas in Model 2.1a, the coefficient of ROA is 0.0614 . The difference between them now lies at the coefficient of GROUPTWO*ROA (equal to -0.0353). As mentioned, the interaction variable is to isolate the effect of foreign ownership on the financial performance of a firm. The negative and statistically significant coefficient of the interaction term GROUPTWO*ROA in Model 2.1a indicates that FDI creates reverse effects on FDI firms' technical efficiency, which may be due to a generally favourable institutional environment (low taxation, financial benefits, etc.).

The negative and statistically significant coefficient of the interaction term GROUPTWO*ROA (ROE) in Model 2.1b, Model 2.1c, Model 2.1d at 1\% level in Table 5 also indicates that FDI creates reverse effects on FDI firms' technical efficiency.

In Model 2.2 we introduce the interaction variable GROUP*ROA or GROUP*ROE to isolate the effect of foreign ownership on the financial performance of a firm in terms of its $R O A$ (or ROE) index, but ownership variable has four categories: 0 if domestic (group 1), 1 if wholly foreign-owned (group 2), 2 if SOE with FDI (group 2), and 3 if PTE with FDI (group 4). The estimation results are in Table 7.

The results from all specifications of Model 2.2 appear to be consistent and robust with those of Model 1with respect to variables such as lag of technical efficiency, labour, capital, ages at three forms, equity to assets, and wage in terms of signs, magnitude of coefficients, and with those of Model 2.1 with respect to variables such as lag of technical efficiency, labour, capital, ages at three forms, equity to assets, wage, ROA and ROE in terms of signs, magnitude of coefficients.

The negative and statistically significant coefficient of the interaction term GROUP1*ROA in Model 2.2a indicates that FDI creates reverse effects on FDI firms' technical efficiency, which may be due to a generally favourable institutional environment (low taxation, financial benefits, etc.).

The negative and statistically significant coefficient of the interaction term GROUP1*ROA (ROE) in Model 2.2b, Model 2.2c, Model 2.2d in Table 7 also indicates that FDI creates reverse effects on FDI firms' technical efficiency.

\subsection{Model of Technological Diffusion with the Impact of Ownership over Firm Characteristics}

In Model 3.1 introduces the interaction variable GROUPTWO*ETA to isolate the effect of foreign ownership on the financial performance of a firm in terms of its equity to assets. The estimation results are in Table 6 in which ownership variable has two categories: 1 if domestic, 0 if FDI.

The results from all specifications of Model 3.1 appear to be consistent and robust with those of Model 1 with respect to variables such as lag of technical efficiency, labour, capital, ages at three forms, equity to assets, and wage in terms of signs, magnitude of coefficients.

The level of self-financing (ETA) exerts a negative impact on technical efficiency scores, about 0,1 per cent in all model specifications of Model 3.1 indicating that firms with increased levels of external financing display an aggressive and expanding behaviour which leads them to higher technical efficiency levels. The interaction term GROUPTWO*ETA displays a similar behavioural pattern with the negative impact on technical efficiency scores, about 3 - 4 per cent in all model specifications of Model 3.1, and indicating that FDI creates reverse effects on FDI firms' technical efficiency, which may be due to a generally favourable institutional environment (low taxation, financial benefits, etc.).

Model 3.2 introduces the interaction variable GROUP*ETA to isolate the effect of foreign ownership on the financial performance of a firm in terms of its equity to assets, but ownership variable has four categories: 0 if domestic (group 1), 1 if wholly foreign-owned (group 2), 2 if SOE with FDI (group 2), and 3 if PTE with FDI (group 4). The estimation results are in Table 6.

The results from all specifications of Model 3.2 appear to be consistent and robust with those of Model 1 with respect to variables such as lag of technical efficiency, labour, capital, ages at three forms, ROA, ROE, and wage in terms of signs, magnitude of coefficients, and with those of Model 3.1 with respect to variables such as lag of technical efficiency, labour, capital, ages at three forms, wage, and ROA, ROE in terms of signs, magnitude of coefficients. 
Table 6. Technological diffusion model in the manufacturing sector in Vietnam (Model 3), 2005-2013.

\begin{tabular}{|c|c|c|c|c|c|c|c|c|}
\hline VARIABLES & Model 3.1a & Model 3.1b & Model 3.1c & Model 3.1d & Model 3.2a & Model 3.2b & Model 3.2c & Model 3.2d \\
\hline L. tech_ & $0.227^{* * *}$ & $0.246^{* * *}$ & $0.216^{* * *}$ & $0.236^{* * *}$ & $0.227^{* * *}$ & $0.246^{* * *}$ & $0.217^{* * *}$ & $0.236^{* * *}$ \\
\hline log_ldong_ & $-0.034^{* * *}$ & $-0.032^{* * *}$ & & & $-0.034^{* * *}$ & $-0.032^{* * *}$ & & \\
\hline age & $-0.015^{* * *}$ & $-0.012^{* * *}$ & $-0.010^{* * *}$ & $-0.008^{* * *}$ & $-0.015^{* * *}$ & $-0.012^{* * *}$ & $-0.010^{* * *}$ & $-0.001^{* * *}$ \\
\hline age 2 & $-0.000^{* *}$ & $-0.000^{* * *}$ & $-0.000^{* * *}$ & $-0.001^{* * *}$ & $-0.000^{* *}$ & $-0.000^{* * *}$ & $-0.000^{* * *}$ & $-0.001^{* * *}$ \\
\hline age 3 & $0.000^{*}$ & $0.000^{* *}$ & $0.000^{* * *}$ & $0.000^{* * *}$ & $0.000^{*}$ & $0.000^{* *}$ & $0.000^{* * *}$ & $0.000^{* * *}$ \\
\hline equity_to_assets_ & -0.001 & -0.000 & -0.001 & & $-0.038^{* * *}$ & $-0.028^{* * *}$ & $-0.044^{* * *}$ & $-0.045^{* * *}$ \\
\hline roa_ & $0.036^{* * *}$ & & $0.021^{* * *}$ & & $0.036^{* * *}$ & & $0.021^{* * *}$ & \\
\hline wage_ & $0.000^{* * *}$ & $0.000^{* * *}$ & $0.001^{* * *}$ & $0.001^{* * *}$ & $0.000^{* * *}$ & $0.000^{* * *}$ & $0.001^{* * *}$ & $0.001^{* * *}$ \\
\hline grouptwo_eta & $-0.037^{* * *}$ & $-0.025^{* * *}$ & $-0.043^{* * *}$ & $-0.045^{* * *}$ & & & & \\
\hline roe_ & & $0.000^{* * *}$ & & $0.000^{* * *}$ & & $0.000^{* * *}$ & & $0.000^{* * *}$ \\
\hline log_von_ & & & $-0.023^{* * *}$ & $-0.024^{* * *}$ & & & $-0.023^{* * *}$ & $-0.024^{* * *}$ \\
\hline group 2_eta & & & & & $0.039^{* * *}$ & $0.029^{* * * *}$ & $0.046^{* * *}$ & $0.050^{* * *}$ \\
\hline Constant & $0.67^{* * *}$ & $0.63^{* * * *}$ & $0.66^{* * *}$ & $0.65^{* * *}$ & $0.67^{* * *}$ & $0.63^{* * *}$ & $0.67^{* * *}$ & $0.66^{* * *}$ \\
\hline Observations & 10,852 & 9762 & 10,852 & 9762 & 10,852 & 9762 & 10,852 & 9762 \\
\hline $\mathrm{R}$-squared & 0.22 & 0.21 & 0.26 & 0.25 & 0.22 & 0.21 & 0.26 & 0.25 \\
\hline Number of id & 1392 & 1392 & 1392 & 1392 & 1392 & 1392 & 1392 & 1392 \\
\hline F test that all $u_{-} i=0$ & $3.46^{* * *}$ & $3.02^{* * * *}$ & $3.82^{* * *}$ & $3.41^{* * *}$ & $3.47^{* *}$ & $3.03^{* * * *}$ & $3.84^{* * * *}$ & $3.42^{* * * *}$ \\
\hline
\end{tabular}

Sources: Authors' calculation from EC 2005-2013. Note: Standard errors in parentheses; 0.000 : less than $0.001 ; \stackrel{* * *}{p}<0.01, \stackrel{* *}{p}<0.05,{ }^{*} p<0.1$.

Table 7. Technological diffusion model in the manufacturing sector in Vietnam (Model 4), 2005-2013.

\begin{tabular}{|c|c|c|c|c|c|c|c|c|}
\hline VARIABLES & Model 4.1a & Model 4.1b & Model 4.1c & Model 4.1d & Model 4.2a & Model 4.2b & Model 4.2c & Model 4.2d \\
\hline L. tech_ & $0.227^{* * *}$ & $0.246^{* * *}$ & $0.216^{* * *}$ & $0.236^{* * *}$ & $0.227^{* * *}$ & $0.246^{* * *}$ & $0.216^{* * *}$ & $0.236^{* * *}$ \\
\hline log_ldong_ & $-0.025^{* * *}$ & $-0.022^{* * *}$ & & & $-0.029^{* * *}$ & $-0.027^{* * *}$ & & \\
\hline age & $-0.016^{* * *}$ & $-0.012^{* * *}$ & $-0.010^{* * *}$ & $-0.007^{* * *}$ & $-0.016^{* * *}$ & $-0.012^{* * *}$ & $-0.001^{* * *}$ & $-0.001^{* * *}$ \\
\hline age 2 & $-0.000^{* *}$ & $-0.000^{* * *}$ & $-0.000^{* * *}$ & $-0.001^{* * *}$ & $-0.000^{* *}$ & $-0.000^{* * *}$ & $-0.000^{* * *}$ & $-0.001^{* * *}$ \\
\hline age 3 & $0.000^{*}$ & $0.000^{* *}$ & $0.000^{* * *}$ & $0.000^{* * *}$ & $0.000^{*}$ & $0.000^{* *}$ & $0.000^{* * *}$ & $0.000^{* * *}$ \\
\hline equity_to_assets_ & $-0.022^{* * *}$ & $-0.016^{* * *}$ & $-0.025^{* * *}$ & $-0.024^{* * *}$ & $-0.022^{* * *}$ & $-0.016^{* * *}$ & $-0.025^{* * *}$ & $-0.024^{* * *}$ \\
\hline roa_ & $0.033^{* * *}$ & & $0.018^{* * *}$ & & $0.033^{* * *}$ & & $0.018^{* * *}$ & \\
\hline wage_ & $0.000^{* * *}$ & $0.000^{* * *}$ & $0.001^{* * *}$ & $0.001^{* * *}$ & $0.000^{* * *}$ & $0.000^{* * * *}$ & $0.001^{* * *}$ & $0.001^{* * * *}$ \\
\hline grouptwo_l & $-0.011^{* * *}$ & $-0.011^{* * *}$ & & & & & & \\
\hline roe & & $0.000^{* * *}$ & & $0.000^{* * *}$ & & $0.000^{* * * *}$ & & $0.000^{* * *}$ \\
\hline log_von_ & & & $-0.023^{* * *}$ & $-0.023^{* * *}$ & & & $-0.023^{* * *}$ & $-0.024^{* * *}$ \\
\hline grouptwo_k & & & 0.000 & -0.000 & & & & \\
\hline group 1_l & & & & & $-0.010^{*}$ & $-0.008^{*}$ & & \\
\hline group 2_l & & & & & $0.00827^{* *}$ & $0.010^{* *}$ & & \\
\hline Constant & $0.66^{* * *}$ & $0.62^{* * * *}$ & $0.66^{* * *}$ & $0.64^{* * *}$ & $0.66^{* * *}$ & $0.62^{* * * *}$ & $0.66^{* * *}$ & $0.64^{* * *}$ \\
\hline Observations & 10,852 & 9762 & 10,852 & 9762 & 10,852 & 9762 & 10,852 & 9762 \\
\hline $\mathrm{R}$-squared & 0.22 & 0.21 & 0.25 & 0.25 & 0.22 & 0.21 & 0.25 & 0.25 \\
\hline Number of id & 1392 & 1392 & 1392 & 1392 & 1392 & 1392 & 1392 & 1392 \\
\hline$F$ test that all $u \_i=0$ & $3.47^{* * *}$ & $3.03^{* * *}$ & $3.83^{* * *}$ & $3.40^{* * *}$ & $3.46^{* * *}$ & $3.02^{* * * *}$ & $3.83^{* * * *}$ & $3.40^{* * * *}$ \\
\hline
\end{tabular}


Coefficients of equity to assets and the interaction term GROUP2*ETA in Model 3.2 provide an interesting findings. The positive and statistically significant coefficient of the interaction term GROUP2*ETA in Model 3.2 at $1 \%$ level indicates that only wholly foreign-owned firms creates reverse effects on firms' technical efficiency, which may be due to a generally favourable institutional environment (low taxation, financial benefits, etc.).

In Model 4.1 presents the interaction variable GROUPTWO*LABOR (CAPITAL) to isolate the effect of foreign ownership on the financial performance of a firm in terms of its labour (or capital). The estimation results are in Table 7 in which ownership variable has two categories: 1 if domestic, 0 if FDI.

The results from all specifications of Model 4.1 appear to be consistent and robust with those of Model 1 with respect to variables such as lag of technical efficiency, labour, capital, ages at three forms, equity to assets, ROA, ROE and wage in terms of signs, magnitude of coefficients.

Coefficients of equity to assets and the interaction term GROUPTWO*LABOR in model 4.1 provide an interesting findings. The negative and statistically significant coefficient of the interaction term GROUPTWO* LABOR at $1 \%$ level in Model 4.1 indicates that domestic firms creates negative effects on firms' technical efficiency. Note that the coefficients of the interaction term GROUPTWO*CAPITAL in Model 4.1 are not significant at common levels.

Model 4.2 introduces the interaction variable GROUP*LABOR(CAPITAL) to isolate the effect of foreign ownership on the financial performance of a firm in terms of its labour (capital), but ownership variable has four categories: 0 if domestic, 1 if wholly foreign-owned, 2 if SOE with FDI, and 3 if PTE with FDI. The estimation results are in Table 7.

The results from all specifications of Model 4.2 appear to be consistent and robust with those of Model 1 and Model 4.1 with respect to variables such as lag of technical efficiency, ages at three forms, ROA, ROE, equity to assets, and wage in terms of signs, magnitude of coefficients in terms of signs, magnitude of coefficients.

Coefficients of equity to assets and the interaction term GROUP1*LABOR, GROUP2*LABOR in Model 4.2 provide an interesting findings (Table 7). The negative and statistically significant coefficient of the interaction term GROUP1*LABOR at 1\% level in Model 4.2 indicates that domestic firms creates negative effects on firms' technical efficiency. The positive and statistically significant coefficient of the interaction term GROUP2* LABOR at $1 \%$ level in Model 4.2 indicates that wholly foreign-owned firms creates reverse effects on firms' technical efficiency.

\section{Conclusion and Recommendation}

\subsection{Conclusion}

Factors affecting technological diffusion between all kinds of FDI and domestic manufacturing enterprises in Vietnam within the framework of this investigation are named as follows: 1) Firm's past performance: Positive relationship between firms' past performance and technical efficiency score, 2) Size of a firm in terms of labour and capital: Negative relationship between size of a firm in terms of labour and capital and technical efficiency scores, 3) The firms' financial performance: Positive relationship between firms' financial performance and technical efficiency scores, 4) The firms' level of self-financing: Negative relationship between firms' level of self-financing and technical efficiency scores, 5) The labour market conditions: Positive relationship between the labour market conditions and technical efficiency scores, 6) Years of operation: A quadratic relationship between Years of operation and technical efficiency scores, 7) FDI creates reverse effects in terms of firms' financial performance in terms of ROA, ROE on FDI firms' technical efficiency, 8) FDI creates reverse effects in terms of firms' characteristics (equity to assets ratio, capital, and labour) on FDI firms' technical efficiency. Wholly foreign-owned firms also create reverse effects in terms of equity to assets ratio on firms' technical efficiency. Moreover, wholly foreign-owned firms also create reverse effects in terms of labour on firms' technical efficiency.

\subsection{Recommendations}

\subsubsection{To Policy Makers}

According to the general conclusions of the existence of technological diffusion in manufacturing sector in Vietnam, it is suggested that the government should continue providing the incentives, as it has in the past, to 
encourage FDI within the manufacturing industry. It would be wise, however, to enact this policy with a certain degree of selective support. The reason for this is that, as the study has shown, the presence of FDI firms, will impact domestic firms differently depending upon the different attributes of domestic firms, namely: firm performance (ROA, ROE), firm characteristics (size, self-financing level, years of operation), market conditions (wages).

One of the foremost determinants as to whether a positive technological spillover or a negative spillover occurs will play out according to the size of the firm. The focus for this policy of FDI encouragement should be on small domestic firms. This is the group of domestic firms that benefit the most from FDI. In concert with the encouragement of FDI at this level, the government should leverage the opportunity that this provides and work to create specific programs that will support and help the small firms learn from foreigners. In addition, any program that helps strengthen the linkage and connection between small and medium-sized domestic firms and the foreign firms should be implemented due to the mentoring effect that this will promote.

Policy implications for each manufacturing sub-sectors with regard to current industry technology levels are also different. The promotion of FDI should focus: 1) on the low-technology industries such as "Food products, beverages, and tobacco products", "Textiles, wearing apparel, leather and related products", "Wood and of products of wood and cork, except furniture, articles of straw and plaiting materials", "Paper and paper products", and "Furniture", or 2) on the medium-technology industries such as "Coke and refined petroleum products, chemicals and chemical products, basic pharmaceutical products and pharmaceutical preparations", and "Other non-metallic mineral products", or 3) on the high-technology industries such as "Motor vehicles, trailers and semi-trailers, other transport equipment", and "Computer, electronic and optical products, electrical equipment, machinery and equipment.

\subsubsection{To Administrators at Various Levels in Vietnam}

The competition for FDI is becoming tougher in a globalization context. Meanwhile, Vietnam's investment environment is currently less competitive than other countries in the region. Therefore, improving the investment environment is critical. As the primary goal of foreign investors is to exploit profits, lowering business and investment costs and making the environment more favourable will promote further FDI inflows. For the host country, employment, technology transfer and long term investment from foreign investors are also the objectives for improving investment environment.

Thus, policies should focus on these issues:

Improve the markets for factors of productions, particularly markets for capital, labour, and real estate. This will provide the foreign investors with easier access to and more flexible use of factors of production regarding price, space and time. Otherwise, the underdevelopment of those markets in Vietnam become a severe weakness as it increases the production costs and hinder the ability to capture business opportunities of foreign investors.

Improve and expedite the administrative reform, together with the decentralization of State management in general and investment management in particular to local government. In addition, the responsibility of each individual should be clearly determined and evaluated on the basis of benefits to the whole society. That is, decentralization should enable governments of each level to actively make decisions within their jurisdiction, as well as to evaluate the actual consequences of such decisions, regarding employment creation, increase in production values and added values to local area, etc., after the projects commence. The local policy to quickly improve the capacity of the staff is also required.

The government should support local provinces in promoting investment, training human resources to meet the demand for skilled workers and managerial labours. Building infrastructure facilities, therefore, may give more priority to some potential local provinces, to establish a belt surrounding large cities so that the FDI enterprises may expand their activities with respect to geographical location.

\section{References}

[1] World Bank (1993) Foreign Direct Investment-Benefits beyond Insurance. Development Brief (Vol. 14), Washington DC.

[2] Harrison, A. (1996) Determinants and Effects of Direct Foreign Investment in Cote d'Ivoire, Morocco, and Venezuela. In: Robers, M.J. and Tybout, J.R., Eds., Industrial Revolution in Developing Countries: Micro Patterns of Turnover, Productivity and Market Structure, Oxford University Press.

[3] Liu, Z. (2008) Foreign Direct Investment and Technology Spillovers: Theory and Evidence. Journal of Development 
Economics, 85, 176-193. http://dx.doi.org/10.1016/j.jdeveco.2006.07.001

[4] Aydin, N., Sayim, M. and Yalam, A. (2007) Foreign Ownership and Firm Performance: Evidence from Turkey. International Research Journal of Finance and Economics, 11, 103-111.

[5] Rowland, P. (2006) Foreign and Domestic Firms in Colombia: How Do They Differ? Borradores de Economia, Banco de la Republia de Colombia.

[6] Basti, E. and Akin, A. (2008) The Comparative Productivity of the Foreign-Owned Companies in Turkey: A Malmquist Productivity Index Approach. International Research Journal of Finance and Economic, 22.

[7] Ngo-Quang, T. (2014) Do FDI Enterprises Work More Efficiency than Domestic Ones in Vietnam? Evidence from Panel Data Analysis. Review of Management Innovation \& Creativity (RMIC), 7, Issue 21.

[8] Driffield, N. and Love, J.H. (2003) Foreign Direct Investment, Technology Sourcing and Reverse Spillovers. The Manchester School, 71, 659-672. http://dx.doi.org/10.1046/j.1467-9957.2003.00372.x

[9] Battese, G.E. and Coelli, T.J. (1992) Frontier Production Functions, Technical Efficiency and Panel Data: With Application to Paddy Farmers in India. Journal of Productivity Analysis, 3, 153-169. http://dx.doi.org/10.1007/BF00158774

[10] Acs, Z.J., Audretsch, D.B. and Feldman, M.B. (1994) R\&D Spillovers and Recipient Firm Size. Review of Economics and Statistics, 76, 336-340. http://dx.doi.org/10.2307/2109888

[11] OECD (1993) The Measurement of Scientific and Technological Activities: Standard Practice for Surveys of Research and Experimental Development-Frascati Manual 1993, OECD, Paris. 